\title{
Kente Yakın Su Kaynaklarının Rekreasyonel Amaçlı Değerlendirilmesi
}

\author{
Recreational Evaluation of Water Resources Near the City
}

\author{
Hilal SURAT
}

ÖZ

Deriner Barajı ve çevresi; coğrafi konum, morfolojik özellikleri, iklim, bitki örtüsü, geleneksel kültürel özellikleri ve çeşitliliği ile rekreasyonel amaçlı değerlendirilebilecek önemli bir potansiyeline sahiptir. Yeniden biçimlenmiş bir fiziksel yapıya sahip olan Deriner baraj gölü ve çevresindeki doğal, kültürel ve tarihi zenginliğe sahip alanların hem rekreaktif ve turizm yönüyle kullanılmasına, tanıtılmasına hem de ekolojik olarak sürekliliğinin sağlanabilmesine yönelik öncelikle mevcut durumun ortaya konulması gerekmektedir. Bu amaçla mevut durumu ortaya koyabilmek için SWOT analizi yapılmıştır. Daha sonra SWOT analizi sonucu ortaya çıkan faktörlerin geliştirilmesine ve etkin kullanımlarına yönelik stratejilerin belirlenebilmesi için AHS tekniği kullanılmıştır. Yapılan SWOT analizi sonucunda Deriner Baraj gölü ve yakın çevresinin 9 güçlü yönü, 7 zayıf yönü, 9 fırsat olanağı ve 4 tehtid unsuru ortaya konmuştur. Bu SWOT analiz sonuçları dikkate alınarak yapılan değerlendirmeler sonucu 3 ana ve 7 alt strateji belirlenmiştir.

Anahtar sözcükler: AHS tekniği; Deriner Barajı; kent; rekreasyon; su kaynaklarl; SWOT analizi.

\section{ABSTRACT}

Deriner Dam and its surroundings; geographical location, morphological characteristics, climate, vegetation cover, traditional cultural features and diversity, has an important potential for recreational purposes. Deriner dam lake which has a reconstructed physical structure and its surrounding firstly, the current situation should be put forward natural, cultural and historical richness of both recreational and tourism aspects of the use, promotion and ecological continuity. For this purpose, SWOT analysis was performed to reveal the current situation. Then, AHS technique was used to determine the strategies for the development and effective use of the factors resulting from SWOT analysis. As a result of SWOT analysis has been put forward, 9 strengths, 7 weaknesses, 9 opportunity opportunities and 4 threat elements of Deriner Dam Lake and surrounding. Considering these SWOT analysis results, 3 main and 7 sub-strategies were determined.

Keywords: AHS technique; Deriner Dam; city; recreation; water Resources; SWOT analysis.

Artvin Çoruh Üniversitesi, Sanat ve Tasarım Fakültesi, Peyzaj Mimarlı̆ı̆ Bölümü, Artvin

Başvuru tarihi: 21 Mayıs 2018 - Kabul tarihi: 13 Kasım 2019

İletişim: Hilal SURAT. e-posta: hilal881@artvin.edu.tr

○ 2019 Yıldız Teknik Üniversitesi Mimarlık Fakültesi - @ 2019 Yıldız Technical University, Faculty of Architecture 


\section{Giriş}

Çevre sorunlarıyla birlikte zorlaşan kentsel yaşam şartlarıyla da mücadele eden insanoğlu; bedensel, psikolojik ve sosyal sorunlarıyla iç içe bir yaşam sürmektedir. Hem insanda hem de çevresinde oluşan bu olumsuz değişim, insanoğlunun rekreasyon gereksinimini büyük ölçüde artrrmıştır (Özkan ve Kaplan 1992; Karahan ve Orhan, 2009). Günümüzde artkk insanlar, sağlıksız ve monoton kent yaşamından uzaklaşıp doğaya kaçarak, çalışma ve yaşam koşulları sonucu oluşan yorgunluğunu gidermek için eğlenmeyi ve sosyalleşmeyi sağlayan, boş zamanlarını değerlendirdiği birtakım rekreasyonel faaliyetlere katılmaktadırlar (Koçan 2012).

Rekreasyon, latince "re-tekrar" ve "create-yaratma" sözcüklerinden türemiştir (Karaküçük 1997; Akten, 2003; Karahan ve Orhan, 2009). Daha açık bir ifade ile rekreasyon kişilerin çalışma dışı serbest zamanları içerisinde (Tocher ve Driver 1973); herhangi kazanma amacı olmadan bireyler üzerinde dış etkilerin baskısı olmadan, içten gelen arzu ve katılım istekleri ve ilgileriyle (Uslu ve Ayaşlıgil; 2007), uzaklaşmak, zevk almaya yönelik eğlenmek, dinlenmek, öğrenmek (Bayraktar 1972) gibi pek çok amaçla, ev dışında veya ev içinde, açık veya kapalı alanlarda ya da pasif-aktif şekillerde, kent içinde veya kırsal alanlarda etkinliklere katılması olayı olarak tanımlanmaktadır (Karaküçük, 1999, Uzun ve Altunkasa, 1991). Rekreasyon artik toplumların vazgeçemedikleri bir gereklilik olmuştur. Rekreasyonel faaliyetlere katılmak amacıyla, kent yakın çevrelerinde doğal nitelikli, işlevsel kırsal rekreasyonel alanlara yönelmişlerdir (Özkan ve Kaplan, 1992).

Toplumlar için önemli olan rekreasyon olgusunu ve alanların rekreasyonel değerini belirleyen, etkileyen pek çok faktör bulunmaktadır. Bu faktörlerin başında rekreasyonel doğal faktörler (eğim iklim, yaban hayat, floristik çeşitlilik, su kaynağının varlığı, alan kullanımı vb.), rekreasyonel alt ve üst yapı faktörleri (ulaşım-haberleşme-konaklama olanakları, sağlık tesis varlığı vb.) ile rekreasyonel sosyal faktörler gelmektedir (Albay, 2006; Karahan ve Orhan, 2009; Topay ve Memlük, 2011; Çetin 2015).

Bu doğal faktörlerden bir tanesi olan su kaynakları ve yakın çevreleri, yeryüzündeki başka hiçbir ekosistemle karşılanamayacak işlev ve değerlere sahip, insanoğlunun yiyecek, çoğalma ve öğrenmeyi sağlayabildiği, birçok yerleşim alanının kurulduğu, uygun iklimsel özellikleri ve sunduğu manzara ile eğlenceli zaman geçirilebilecekleri, insan sağlığı üzerindeki olumlu etkileri olan en ideal yaşam alanları ve rekreasyonel yönden potansiyeli yüksek alanlar olmuştur (William, 1973; Khazim, 1990; Cendere, 1998; Kılıç, 2001; Yılmaz, 2006; Karahan Ve Orhan, 2009).

Su öğesi, sakinliği ile uyandırdığı his ve duygular, sıradışı farklıı̆̆ı yanı sıra sıcak bir ortam oluşmasını sağlayan ve boş zaman faaliyetleri için yarattğı firsatlar bütünü ile her zaman önemli bir tasarım elemanı olmuştur. Su, bir kompozisyon içinde kendine yer bulabilen peyzajdaki en ilginç obje olup, uzaktan gözü cezbeder, davetkârdır, zevk verir, sıkıcılığı azaltır, manzarayı zenginleştirir ve netleştirir. Şekil, kapsam ve büyüklük olarak keskinliği yumuşatarak sakin bir alana yayılabilir ya da kıvrımlı hareketlerle durağanlığa ve sıkıcılı̆ga son veren romantik bir elemandır (Fairbrother, 1976; Wylson, 1986; Karahan ve Orhan, 2009).

Tarihi boyunca insanoğlu suyun bulunduğu ortamlarda yerleşime yönelmiş, estetik ve fonksiyonel amaçlarla sudan yararlanmıştır. Çağlar boyunca su, yaşama mekanlarının biçimlenmesi ve tasarlanmasında etkili bir faktör olmuştur. Suyun klimatik özelliklerinin bulunmasının yanısıra görsel estetik özelliklere sahip olması peyzajda vazgeçilmez bir tasarım unsuru haline gelmesini sağlamıştır (Memlük ve ark., 1994). Aynı zamanda su kaynaklarının arazinin şeklini ve bitki örtüsünü etkilemesi, peyzaja farklılık katması, bulunduğu ortama görsel ve işitsel etkisi, duyumsal haz, iklimsel konfor, sirkülasyon kontrolü olmak üzere estetik ve fonksiyonel yönden bir takım özellikler kazandırmaktadır. (Kılıç 2001; Hamamcıoğlu, 2005; Önen 2007).

Birçok bilimsel araştırma, su yüzeyleri ve çevrelerinin rekreasyon amaçlı en çok tercih edilen alanlar olduğunu ve su kaynağı ve çevresinde yapılan rekreasyonel etkinliklerin insanların fiziksel ve ruhsal yapıları, görsel, işitsel, dokunsal özellikleri, birey ve toplum psikolojisi üzerine olumlu katkılarda bulunduğunu göstermiştir (Hattapoğlu, 2004; Uğurlu, 2005).

Baraj gölleri ve yakın çevreleri de rekreasyonel amaçlı kullanımları giderek artan, turizm ve rekreasyon açısından en büyük zenginliği, flora ve faunayı su ortamıyla birlikte sunabilen su kaynaklarından bir tanesidir. 1945 yılından itibaren baraj alanları ve çevrelerinde, kamp yapma, manzara seyretme, balık tutma, sandalla dolaşma ve diğer su sporları için rekreasyonel faaliyetlerin gerçekleştirilebileceği alanlar olmuştur (Memlük, 1977; Doğaner 2001; Özkazanç, 2005). Ülkemizde ise hızlı kentleşme, yasam şartlarının zorlaşması, büyük kentlerdeki zaman yetersizliği ve sosyo-ekonomik nedenlerle bir denize kıyısı olmayan illerde doğal göl ve yapay göller ile baraj gölleri ve çevreleri piknik yapmak dışında farklı rekreasyonel aktivitelerin gerçekleştirilebileceği değerli alanlar olmuştur (Yılmaz ve Özel, 1999; Tanrıvermiş, 2000).

Hem ulusal hem de uluslararası bir çok önemli özelliğe sahip baraj alanları ve çevreleri bulundukları bölgelerde rekreasyonel olanaklardaki gelişmeye paralel olarak çekicilik yaratmakta, daha çok ziyaretçinin gelmesini, alt yapının geliştirilmesini, bölgenin/yörenin kalkınmasını artırmaya yönelik katkılar sağlamaktadır. Baraj alanları ve çevrelerinin sanayi ve endüstri yerine rekreasyonel amaçla kullanılması ekolojik açıdan daha olumlu sonuçlar oluşturmaktadır. Bu alanlar ekolojik sürekliliğin sağlanabileceği doğal kaynak 
alanlarıdır. Bu kaynakların ekonomiye dönüşümü şeklinde fayda sağlamakla birlikte ziyaretçilere doğal, kültürel ve tarihi özellikleriyle zengin alanları tanıma ve yaşama firsat sunarlar. Aynı zamanda zengin bitki örtüsü ve faunasıyla ayrıcalıklı hassas ekosistemlerdir. Barajlar ve çevreleri taşıdıkları özellikleri itibari ile farklı bölge ve yükseltilerde farklı rekreasyonel olanaklar sunabilmektedir. Rekreasyonel açıdan su, hem karasal hem de suya ve kıyıya dayalı etkinlikler için önemli bir ortamdır (Boud-Bovy ve Lawsom, 1998).Bu nedenle, günümüz insanının rekreasyon gereksinmelerinin karşılanmasında önemli yeri olan su kaynakları ve çevreleri ile ilgili akılcı planlama ve yönetim çalışmalarının yapılması önem taşımaktadır.

Çoruh vadisi de, morfolojik yapıya bağlı olarak çevresine oranla farklı iklimsel karaktere sahip, ekolojik, biyolojik, kültürel ve sosyo-ekonomik özellikleri ile farklı peyzaj karakterleri sunmaktadır. Çoruh vadisi üzerinde yapımı henüz tamamlanmış olan Deriner barajı ile mevcut arazi yapısı fiziksel yönden yeniden biçimlenmiştir. Bu yeni biçimlenme sonucu görsel nitelikleri yüksek ve rekreasyonel kullanımlara olanak tanıyan prestijli alanlar oluşmuştur.

Bu çalışmanın amacı, yeniden biçimlenmiş bir fiziksel yapıya sahip olan Deriner baraj gölü ve çevresindeki doğal, kültürel ve tarihi zenginliğe sahip alanların hem rekreaktif ve turizm yönüyle kullanılmasına, tanıtılmasına hem de ekolojik olarak sürekliliğinin sağlanabilmesine yönelik planlama çalışmalarının yapılabilmesi amacıyla alanın sahip olduğu mevcut durumu ortaya koymaktır. Bu sebeple çalışma kapsamında hem mevcut durum ortaya konmaya çalışılmış hem de kent yakın çevresinde gerçekleştirilebilecek rekreasyonel etkinlikler için önemli bir ortam sunan baraj ve çevresinde ilde yaşayan ve ile ziyaret amacı ile gelen insanların rahatlıkla yararlanabilecekleri, doğal alan ve kaynaklara yönelik rekreasyon etkinliklerini geliştirmek için fiziki ve sosyal çevreyi bir bütün içinde ele alan, ekolojik kriterlere uygun rekreasyonel potansiyelinin değerlendirilmesine yönelik olarak stratejiler belirlenmiş̧ir.

\section{Materyal ve Yöntem}

\section{Materyal}

Çalışmanın ana materyalini Deriner Barajı ve çevresi oluşturmaktadır. Çalışmada alanın doğal ve kültürel özelliklerinin belirlenmesi ve planlamaya ilişkin önerilerin geliştirilebilmesi için geniş kapsamlı literatür taraması yapılmıştır. Alana farklı mevsimlerde gidilmiş, yerinde gözlem ve değerlendirmeler yapılmıştr. Deriner Baraj göl alanının bulunduğu güzergah üzerinde araştırma ve gözlemler yoğunlaştrılmıştır.

Araştrrmada öncelikle baraj alanı ve çevresinin rekreasyonel açıdan mevcut durumu, güçlü ve zayıf yönleri, ileriye dönük olarak da sunduğu olanaklar ve olası kısıtlamaların neler olduğunu belirlemek amacıyla SWOT (Streght, Weakness, Opportunity, Threatment) analiz yöntemi kullanıl- mıştır. Bu analiz yöntemi ile güçlü yönlerin ve firsatların değerlendirilmesi ve zayıf yönlere ve tehdit unsurlarına karşı alınacak tedbirlere yönelik öneriler getirilmiştir. Bu bağlamda Deriner barajı ve çevresinin rekreasyonel potansiyelinin mevcut durumunun ilk defa bütüncül olarak araştrılması ve paydaşların araştırmaya dahil edilmesi yönüyle önemli bir çalışmadır. SWOT analizi, yöreyi bir bütün olarak ele alarak mevcut durumunu ayrıntılı olarak incelemesi, turizm ve rekreasyon potansiyelinin ortaya koyması ve yöreye uygun strateji ve politikaların oluşturulması açısından büyük önem taşır (Güngör ve Arslan, 2004; Birdir vd., 2015).

\section{Yöntem}

Bu çalışmada "Sayısal SWOT Tekniği" olarak adlandırılan SWOT ve Analitik Hiyerarşi Prosesin (AHP) birlikte kullanıldığı melez teknik uygulanmıştır. Çalışmada öncelikle, baraj alanı ve çevresinin rekreasyonel potansiyeli ile ilgili mevcut durumun anlaşılması, güçlü ve zayıf yönlerin belirlenmesi, yüz yüze olunan tehditler ve firsatların daha net görülmesini sağlayacak bir tabloyu ortaya koyacak SWOT matrisi (Tablo 1) oluşturulmuştur (Taşcıoğlu ve Akpınar, 2016). SWOT matrisi oluşturulmasında, yörede (arazide) yapılan gözlem, inceleme ve görüşmelerden elde edilen bilgilerin yanı sıra, yöre ile ilgili; kitap, makale, bildiri, araştırma raporu, gibi bilimsel çalışmalar yol gösterici olmuştur. Sözel (kalitatif) değerleri içeren SWOT analizinin daha doğru sonuçlar vermesi amacıyla baraj alanı ve çevresinin rekreasyonel potansiyeline yönelik uzman anketi ile desteklenen AHP (Analitik Hiyerarsi Prosesi) Tekniği uygulanmıştr.

SWOT (Üstünlükler, Zayıflıklar, Fırsatlar, Tehditler) (Tablo 1) analizi karar verme sürecinde önemli bir destekleyici bir araç olduğu gibi, aynı zamanda de karar vericinin hedefleriyle uyumlu iyi strateji geliştirmenin önemli bir adımıdır (Akbulak 2016). Fakat SWOT analizinde faktörlerin ağırlıklarının stratejiler üzerindeki etkisi/etkileri sayısal olarak değerlendirilememektedir. Bu yüzden kaynak değeri olan alanların rekreasyonel kullanımlarına yönelik stratejilerinin daha doğru bir şekilde belirlenmesi amacıyla yapılan çaIışmalarda strateji belirleyebilmek amacıyla bütünleşik bir model olan AHS ile SWOT analizi birleştirilerek A'WOT modeli kullanılmaya başlanmıştır (Şekil 1) (Kangas vd., 2001; Kajanus vd., 2004; Taşcıoğlu ve Akpınar 2016).

A'WOT Tekniği'nin ilk aşamasında SWOT çözümlemeleri için öncelikle, her SWOT grubundaki faktör sayısının dokuzdan fazla sayıda olmayacak şekilde değerlendirmeler yapılmaktadır. Sonrasında elde edilen faktörler arasında

Tablo 1. SWOT matrisi

\begin{tabular}{lcc}
\hline İçsel faktörler/Dışsal faktörler & Güçlü yanlar & Zayıf yanlar \\
\hline Fırsatlar & G-F & Z-F \\
Tehdit ve tehlikeler & G-T & Z-T \\
\hline
\end{tabular}




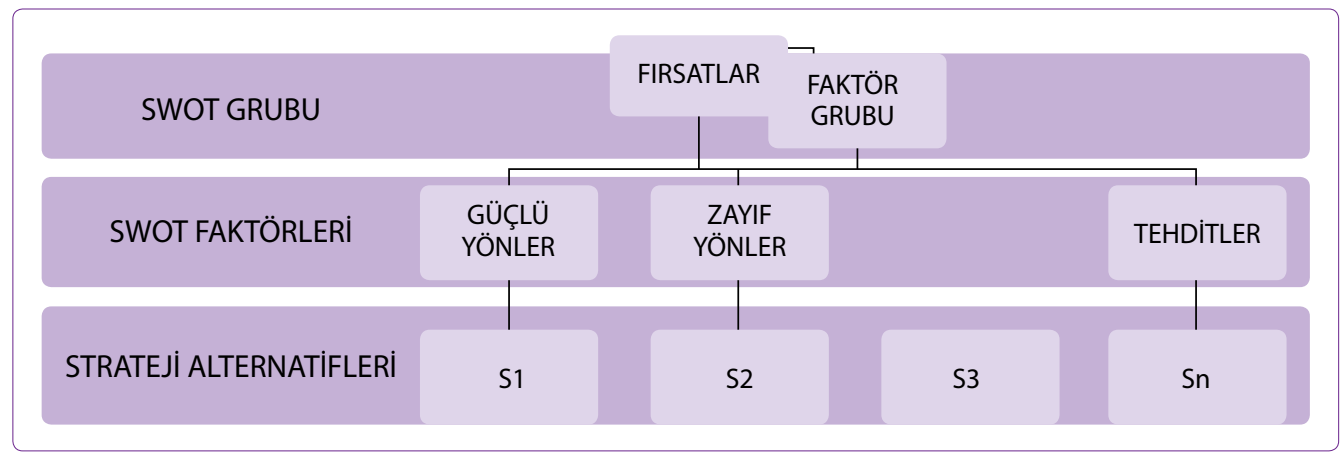

Şekil 1. A'WOT analizinin hiyerarşik sunumu.

Tablo 2. Analitik Hiyerarşi Yöntemi Önem Skala Değerleri ve Tanımları (Saaty 1983-1987)

\begin{tabular}{lll} 
Skala Değeri & Tanım & Açıklama \\
\hline 1 & Eşit Önemli & İki seçenek eşit derecede öneme sahip \\
3 & Biraz Önemli & Bir seçenek diğerine karşı biraz daha üstün \\
5 & Kuvvetli Derecede Önemli & Bir seçenek diğerine karşı oldukça üstün \\
7 & Çok Kuvvetli Derecede Önemli & Bir seçenek diğerine göre çok üstün \\
9 & Kesin Önemli & Bir seçeneğin diğerinden üstün olduğunu \\
& & gösteren kanıt çok büyük güvenilirliğe \\
& sahiptir \\
$2,4,6,8$ & Ara Değerler & Uzlaşma gerektiğinde kullanılmak üzere iki \\
& & ardışık yargı arasındaki değerler
\end{tabular}

uzman grup tarafindan "hangi faktör daha çok (önemlidir)?" ve sonrasında, "daha çok tercih edilen faktör diğer faktöre göre ne kadar daha çok tercih edilmektedir?" şeklinde karşılaştırmaları yapmaları istenmektedir (Tablo 2). $\mathrm{Bu}$ karşılaştırmalardan elde edilen bilgilere göre, SWOT faktörlerinin öncelikleri hesaplanmaktadır. Ardından temsilen her SWOT grubundan en yüksek öncelik değerine sahip bir SWOT faktörü seçilerek SWOT gruplarının öncelik değerleri hesaplanmaktadır. Sonraki aşamada ise, her SWOT grubunun göreceli öncelik değeri ile bu gruptaki SWOT faktörlerinin her birisinin göreceli öncelik değeri ayrı olarak çarpılarak, her SWOT faktörünün genel öncelik değerine ulaşılmaktadır. Bu işlem, dört SWOT grubunun her birisi için ayrı olarak gerçekleştirilmektedir (Heydarzadegan ve Arslan, 2012; Heydarzadegan, 2013; Taşcıoğlu ve Akpınar, 2016).

\section{Araştırmanın Örneklemi}

Araştirmada kullanılan "SWOT Analizi Formunu" dolduracak ve "Alternatif Stratejilerin" oluşturulmasında görüşlerini bildirecek katılımcıların belirlenmesinde amaçlı örnekleme yöntemlerinden maksimum çeşitlilik örneklemesi kullanılmıştir. Maksimum çeşitlilik örneklemesinde küçük bir örneklemde çalışılan probleme taraf olabilecek bireylerin çeşitliliğini maksimum derecede yansıtılması ön planda tutulmaktadır (Yıldırım ve Şimşek, 2013; Birdir vd., 2016). Araştırmanın örneklemi olasılık dışı örnekleme türlerinden olan, amaçlı (yargısal) örneklemeye göre belirlenmiştir. Amaçlı örneklemede araştırmacı kimlerin seçileceği konusunda kendi yargısını kullanır ve araştırmanın amacına en uygun olanları örnekleme alır (Balcı, 2005; Özan vd., 2015). Bu kapsamda, yönetici, akademisyen ya da uzman konumunda çalışan il Kültür ve Turizm Müdürlüğünden, Artvin Orman Bölge Müdürlüğünden, Artvin Orman İşletme Müdürlüğünden, DSi 26. Artvin Bölge Müdürlüğünden, farklı seyahat acentalarından ve Artvin Çoruh Üniversitesi Orman Fakültesinden olmak üzere toplam 25 kişi ile görüşülmüştür.

\section{Araştırmada Kullanılan Veri Analiz Tekniği}

SWOT Analizi için katılımcılardan alınan cevaplar, bilgisayar ortamına aktarılırmıştır. Elde edilen veriler tekrarlanma düzeyine göre sıralanarak yorumlama yoluna gidilmiştir. Daha sonra, elde edilen bilgiler tablolaştrılmış ve katılımcı görüşlerine göre öneriler sunulmuştur. Anketlerden elde edilen nicel veriler Microsoft Office Excel ve Expert Choice 11 yazılımları ile nicel verilere dönüştürülerek SWOT ölçütlerinin rekreasyon kriterleriyle olan ilişkileri analiz edilmiştir. Son aşamada ise anketlerin sonuçlarına göre Deriner barajı ve yakın çevresinin rekreasyonel kullanımı için çeşitli stratejiler geliştirilip öneri olarak sunulmuştur.

\section{Çalışma Alanı}

Deriner Baraj gölü çevresindeki Artvin -Şavşat Karayolu üzerinde Sakalar köyüne kadar olan yaklaşık 20 km lik kı- 
sım, Ardanuç-Şavşat Karayolu ayrımından itibaren yaklaşık 24 km'lik kısım ve Artvin-Erzurum karayolu üzerindeki yaklaşı 20 km lik kısım çalışma alanı güzargahı olarak seçilmiştir (Şekil 2). Deriner Barajı, Artvin'de, Çoruh Nehri üzerinde, enerji üretmek amacıyla 1998 yılında inşasına başlanmış bir barajdır. Deriner Barajı ve HES, Doğu Karadeniz Bölgesinde Çoruh Nehri üzerinde ve Artvin II Merkezini Erzurum II Merkezine bağlayan Devlet Karayolu üzerindeki köprünün 5 km membaındadır (Anonim 2011, Anonim, 2014).

Korumada öncelikli 200 Ekolojik Bölgeden biri olarak ilan edilen baraj alanı; hem Çoruh Vadisi önemli bitki alanı hem de Kuzeydoğu Anadolu Bitkisel Çeşitlilik Merkezi (SWA.19 Kuzey Doğu Anadolu) olarak tanımlanan bölgede yer alan tehlike altnndaki en önemli 34 Karasal Ekolojik Bölgesinden biri olan Kafkasya Sıcak noktası (Caucasus Hotspot) içerisinde yer almaktadır. Deriner Baraj aynası altında yayılış gösteren 14'i endemik 2'si endemik olmayan nadir olmak üzere toplam 16 adet bitki türünün Deriner Barajı su aynası altında kaldığı yapılan araştırmalar sonucu belirlenmiştir (Tablo 3) (Anonim, 2011).

Deriner barajı etrafinda bulunan yerleşimler Çoruh nehrinin dar vadisi boyunca sıralanmış olup köyler, vadi yamacının alçak kesimlerinde bulunmaktadır. Baraj aynası altında kalan Kalburlu, Zeytinlik ve Oruçlu köylerinin yanısıra güzergah üzerinde Hamamlı, Çimenli, Sakalar, Ferhatlı, Soğanlı, Gümüşhane, Köseler köyleri de bulunmaktadır (Şekil 3). Deriner barajının yapılması ve rezervuar alanının su tutmaya başlamasıyla, Kalburlu, Zeytinlik ve Oruçlu Köyleri bulundukları yükseltiden daha yüksek kotlara taşınma zorunluluğu ortaya çıkmıştır. Oruçlu köyü sakinleri yeni yerleşim yeri olarak, mezraa yerleşim alanlarını kullanmaya başlamışken, Zeytinlik köyü sakinleri, eski yerleşim yeri ile Artvin-Erzurum (D-950) karayolu arasında kalan kesime yerleşmiştir. Bu yerleşim yerlerinden Zeytinlik (Sirya) köy sınırları içerisinde, 1856 yılında yapılmış tarihi cami ile Oruçlu Köy yerleşim alanı içerisinde 1909 yılında yapılmış tarihi bir cami ile 1900'lü yılların başında Rus işgali döneminde inşa edilmiş gümrük binası (Orhan ve Gök, 2016) yeni yapılan yerleşim yerlerine taşınmıştir. Fakat Çoruh Nehri'nin bir kolu olan Şavşat Deresi'nin üzerinde bulunan Artvin'in Ardanuç, Şavşat ve yöredeki köylerle bağlantısını sağlayan tarihi Berta köprüsü, Zeytinlik (Sirya) köy sınırları içerisinde Selçuklu dönemine ait olduğu düşünülen iki türbe (Aşağı ve Yukarı Zeytinlik Türbeleri), Saltuklu dönemine ait iki kümbet, Selçuklulara ait Ferhatlı Köprüsü, Avcılar Köyü Köprüsü onarımları yapıldıktan sonra baraj aynası altında kalması onaylanmıştır (Şekil 3) (Anonim 2013 artvin bülten sayı:8).

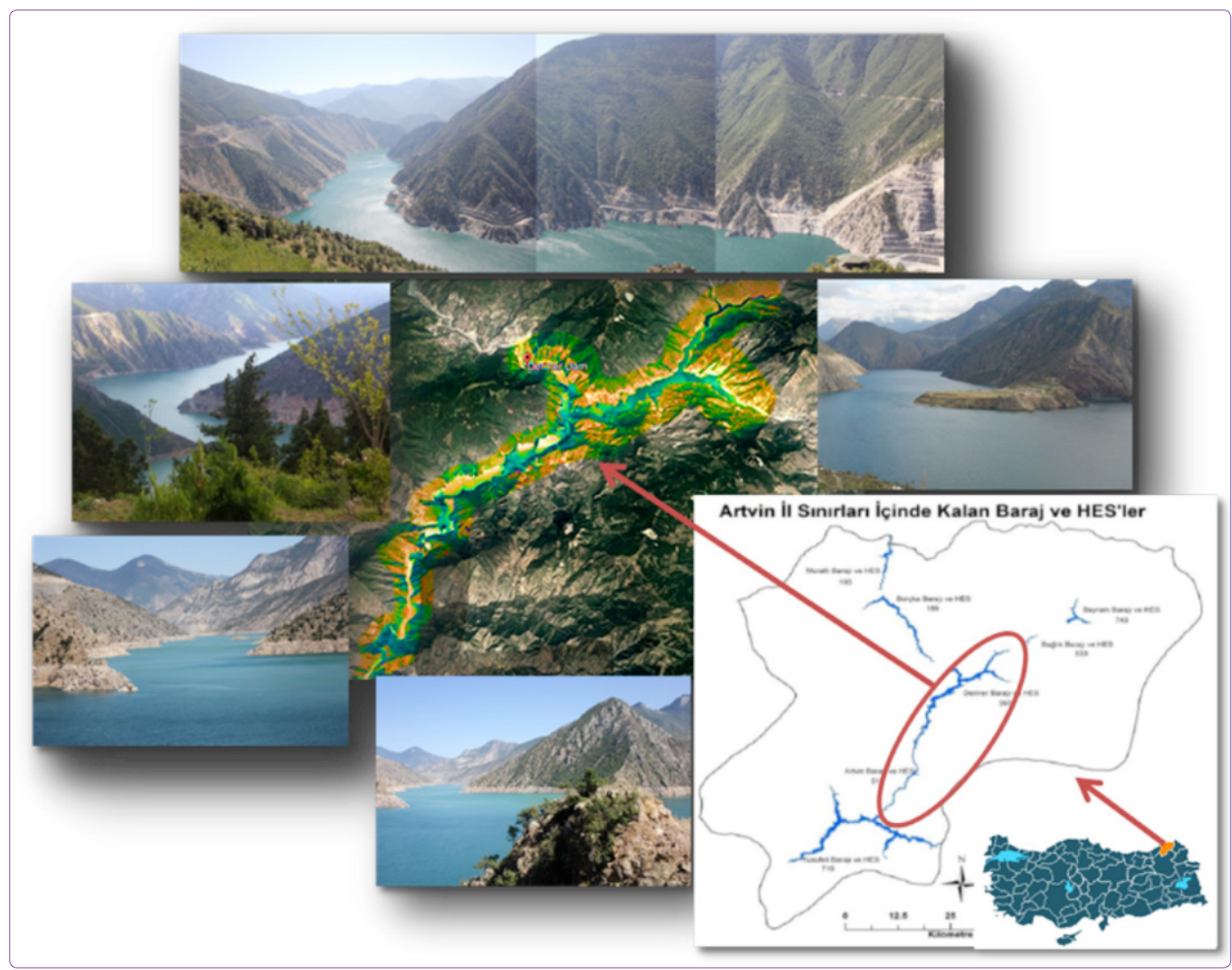

Şekil 2. Çalışma alanının konumu ve çevresinden görüntüler. 
Tablo 3. Çoruh Vadisi-Deriner Barajı su aynası altında kalan endemik-nadir bitki türleri ve görüntüleri (Anonim, 2011).

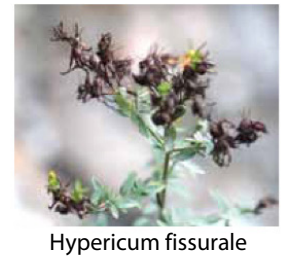

Hypericum fissurale

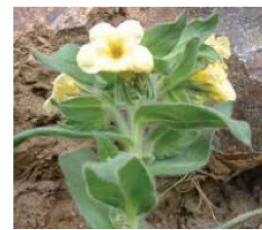

Alkanna cordifolia
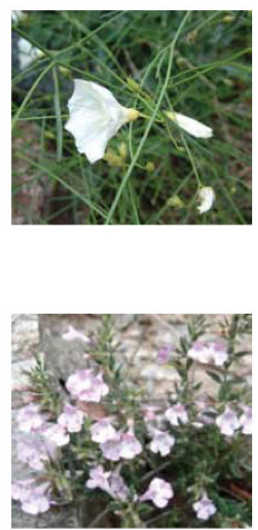

Micromeria elliptica

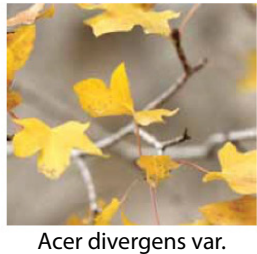

Divergens

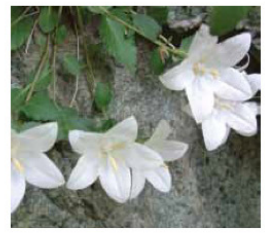

Campanula troegerae
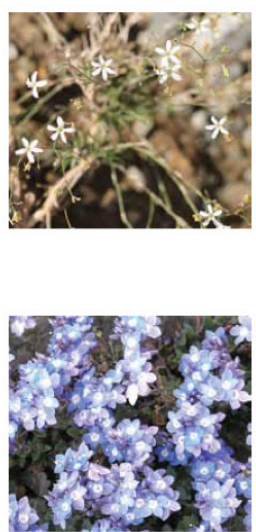

Veronica liwanensis

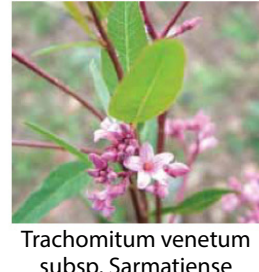

subsp. Sarmatiense

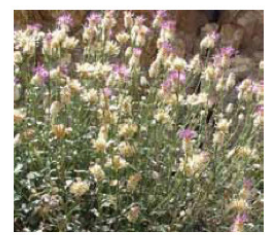

Centaurea pecho
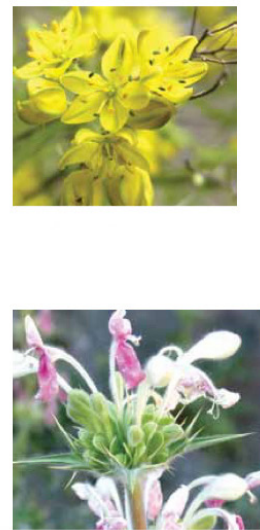

Morina persica

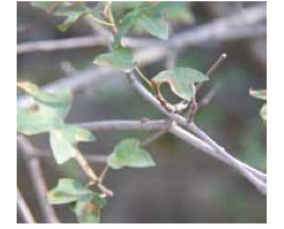

Acer divergens var. trilobum
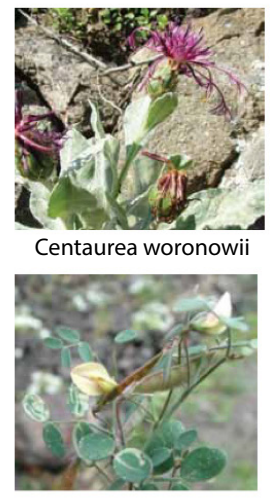

Lathyrus woronowii

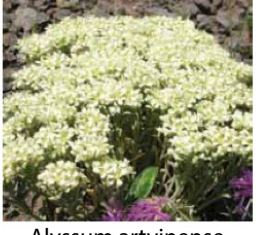

Alyssum artvinense

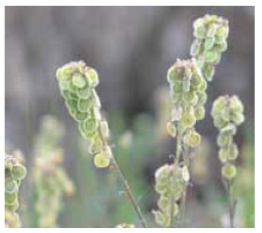

Clypeola raddenea

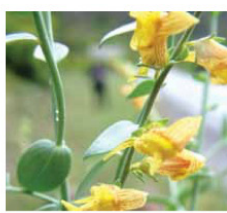

Linaria genistifolia subsp. Artvinensis

\section{Bulgular ve Tartışma}

Çalışmada, Deriner Barajı ve yakın çevresinin turizm ve rekreasyonel potansiyeli olan alanların geliştirilmesine yönelik bir değerlendirme yapabilmek için doğal kaynak değerleri, tarihi yapı mirası, erişilebilirlik, ulaşım, alt yapı vb. özelliklerin güçlü ve zayıf yönleri ile firsatlar ve tehditlerinden oluşan nitel SWOT analizi çıkarılmıştır. Değerlendirmeler sonucunda ise yörenin rekreasyon potansiyeli ile ilgili 9 güçlü, 7 zayıf yön ile 9 firsat ve 8 tehdit unsuru belirlenmiştir (Şekil 4).

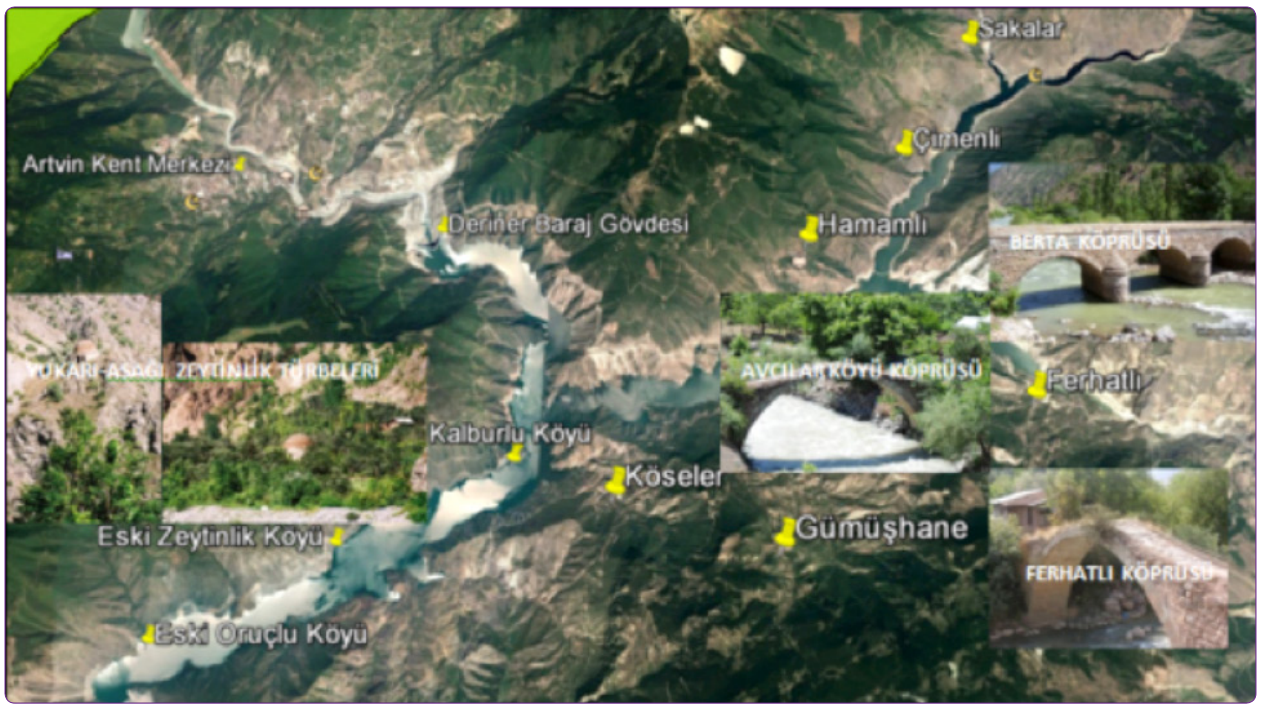

Şekil 3. Çalışma alanı ve yakınında bulunan yerleşim yerleri ve su altında kalan kültür yapıları (RESiMLER: Url1 www.bertakoprusu.com ,12.04.2018). 


\section{SWOT FAKTÖRLERI}

\begin{tabular}{|l|}
\hline \multicolumn{2}{|c|}{ GÜÇLÜ YÖNLER } \\
\hline G1: Zengin flora, fauna varlığı \\
G2: Alan ve yakın çevresinde \\
zengin manzara seyir noktalarının \\
bulunması, foto safari olanağına \\
sahip alanların varlığı \\
G3: Suya dayalı ve çeşitli \\
rekreasyonel faaliyetlere potansiyel \\
oluşturması \\
G4: Alanın konumunun Artvin \\
karayolu koridoru üzerinde ulusal \\
ana ulaşım ağı üzerinde yer alması \\
G5: Değişik rekreasyonel \\
faaliyetlere olanak sağlayan \\
topografik yapı \\
G6: Dünyanın önemli vadilerinden \\
ve nehirlerinden biri olan Çoruh \\
Vadisi ve Çoruh Nehri'nin varlığı \\
G7: Macera ve keşif duygusu \\
uyandıran alanların varlığı \\
G8: Barajın inşa edilmesi ile nehir \\
habitatı göl habitatına dönüşerek \\
yeni bir göl ekosisteminin oluşması \\
G9: Başta su kuşları olmak üzere \\
alana dinlenme, beslenme, \\
barınma hatta kuluçka dönemleri \\
için kuş türlerinin gelmesi \\
\end{tabular}

\begin{tabular}{|l|}
\hline \multicolumn{2}{|c|}{ ZAYIF YÖNLER } \\
\hline Z1: Rekreasyona yönelik hizmet \\
sektörünün gelişmemiş olması ve \\
altyapı ve hizmet kalitesinin ihtiyacı \\
kaşıllayamaması \\
Z2: Finansal ve tanıtım sorunları \\
Z3: Turistik hizmet sektörünün \\
gelişmemiş olması ve turizm \\
yatırımı yapmak için imkanların \\
kısıtı olması \\
Z4: Vatandaşların baraj gölleri \\
konusundaki bilinçli olmamaları \\
Z5: Güzergah üstünde bulunan \\
rekreasyon alanlarına yönelik \\
yönlendirme veya tanıtım \\
tabelaların eksikliği \\
Z6: Toplam 2650 ha. alan göı \\
aynası altında kalacak 14'i endemik \\
2'si endemik olmayan nadir olmak \\
üzere toplam 16 adet bitki türünün \\
Deriner Barajı su aynası altında \\
kalması, \\
Z7: 2 köy yerleşiminin (Zeytinlik ve \\
Oruçlu) ve yerleşimlerde bulunan \\
kültürel miras unsurlarının ve \\
zeytin bahçelerinin baraj suları \\
altında kalması \\
\end{tabular}

\begin{tabular}{|l|}
\multicolumn{2}{|c|}{ FIRSATLAR } \\
\hline \multicolumn{1}{|c|}{} \\
\hline F1: Kent merkezi dışında \\
rekreasyon faaliyetlerini \\
gerçekleştirmek için potansiyeli \\
yüksek alternatif bir kırsal \\
rekreasyon alanı niteliğini taşıması \\
F2: 1960'Iı yıllara kadar Çoruh Nehri \\
üzerinde taşımacılak faaliyetinin \\
yapıımı̧ olması \\
F3:Yönlendirilebilecek işgücünün \\
varlı̆ı \\
F4:Yerel yönetimlerin rekreasyon \\
çalışmalarına yönelik ilgisi ve \\
yatııım yapmaya istekli olması \\
F5: Baraj gölü ve çevresinde \\
rekreasyonel etkinlikleri yapmaya \\
yönelik artan ilgi çekicilik \\
F6: Yöre halkının rekreatif \\
faaliyetlere katııım göstermeye \\
istekli olması \\
F7: Macera ve keşif duygusu \\
uyandıran, görülmeye değer \\
manzaraya sahip alanların varlığı \\
F8: Baraj ve çevresinde yeni mesire \\
ve dinlenme alanlarının oluşması \\
F9: Göl kıyısında kurulacak olan \\
yeni Zeytinlik köyünün manzara \\
avantajından yararlanılarak, kırsal \\
turizme ev sahipliği yapabilecek bir \\
yapıya dönüştürülmesi \\
\hline
\end{tabular}

\begin{tabular}{|l|}
\hline \multicolumn{2}{|c|}{ TEHTiDLER } \\
\hline \multicolumn{1}{|c|}{} \\
\hline T1: Zeytin bahçelerinin sular altında \\
kalması, zeytin tarımı yapılacak \\
uygun arazinin kısıtı olması \\
T2: Köy yerleşimlerinin yer \\
değiştirmesi ile yapılan meskenlerin \\
tamamında geleneksel mimariden \\
uzak konutların inşa edilmesi \\
T3: Doğal, kültürel ve tarihi \\
mirasın korunması konusundaki \\
yetersizlikler ve baraj altında kalan \\
tarihi eserlerin korunmasında \\
yaşanan zorluklar \\
T4: Çevreye ilişkin yasal mevzuatın \\
yetersizliği, mevzuata uyulmaması \\
ve yasal bir yaptııımın olmaması \\
T5: Erozyon alanlarının varlığı \\
rakreasyon alanlarını olumsuz \\
yönde etkilemesi \\
T6: Yapılan rekreasyonel faaliyetler \\
sonucu doğal hayatın zarar \\
görmesine, bitki örtüsünün \\
bozulmasına ve buna bağlı olarak \\
yörenin estetik değerlerinin \\
azalması \\
T7: Alanda yol yapım \\
çalısmalarından kaynakıı \\
bozulmuş olan alanlarda onarım \\
çalışmalarının yetersiz olması \\
\hline
\end{tabular}

Şekil 4. Deriner Barajı ve yakın çevresi için SWOT analizi sonuçları.

Sayısal SWOT analizi sonucunda elde edilen bulgulardan genel SWOT gruplarının ikili karşılaştırma matrisinin ortalama tutarlıık oranı (TO) 0.07 olarak bulunmuştur. Genellikle tutarlılık oranı $\% 10$ yani 0.10 'dan daha küçükse matrisin tutarlı olduğu kabul edilir (Saaty, 1980). Çalışmanın yönteminde kullanılan sayısal SWOT tekniği, elde edilen sonuçlara göre tutarlı bir yapı göstermektedir. AHS tekniği yardımıyla, Deriner baraj gölü ve yakın çevresinde geliştirilecek turistik ve rekreasyonel faaliyetlerin etkileri göz önünde bulundurularak SWOT faktörlerinin öncelik değerleri hesaplanmışttr. SWOT faktörleri arasında en önemli öncelik 'Güçlü Yönler $(0,390)$ ' olarak hesaplanmışttr. 'Fırsatlar' ın önceliği 0,266 'Zayıf Yönler' in önceliği 0,257 ve 'Tehditler' grubunun önceliği ise 0,213 olarak tespit edilmiştir (Tablo 4).

Uzman anketiyle desteklenen Analitik Hiyerarşi Yöntemi sonuçlarına göre; Deriner Baraj gölü ve yakın çevresinin 9 güçlü yönünden $\mathrm{G} 1$ 'in (Zengin flora, fauna varlığı) öncelik değeri 0,405 ve G2 (Alan ve yakın çevresinde zengin manzara seyir noktalarının bulunması, foto safari olanağına sahip alanların varlığı) öncelik değeri 0,387 ile güçlü yönler kategorisinde ilk iki sırada yer almışlardır. Doğanay ve
Zaman (2013) ve Bekar vd., (2018) yapmış oldukları çalışmada potansiyel turistik çekicilik sunan başlı başına birer doğa harikaları olarak değerlendirilen barajlar ve baraj göllerini, zengin flora ve fauna varlığı, eşsiz manzara noktaları oluşturması gibi özelliklerinden dolayı rekreasyonel kullanım açısından öncelikli tercih edilen alanlar arasında yer aldığını belirtmişlerdir. G8 (Barajın inşa edilmesi ile nehir habitat göl habitatına dönüşerek yeni bir göl ekosistemi oluşturması) ve G9 (alana dinlenme, beslenme, barınma hatta kuluçka dönemleri için kuş türlerinin gelmesi) faktörleri 0,285 ve 0,286 yerel öncelik değeri alarak 9 güçlü yön içerisinde son iki sırada yer almışlardır.

Tespit edilen 7 zayıf yönden Z1 (Rekreasyona yönelik hizmet sektörünün gelişmemiş olması ve altyapı ve hizmet kalitesinin ihtiyacı karşılayamaması) yerel öncelik değeri 0.318 ve $Z 7$ ( 2 köy yerleşiminin (Zeytinlik ve Oruçlu) ve yerleşimlerde bulunan kültürel miras unsurlarının baraj suları altında kalması) öncelik değeri 0,309 ile zayıf yönler içerisinde ilk 2 sırada yer almışlardır. Altunöz ve diğ., (2014), Bozkurt (2016) ve Okuyucu ve Menteşe (2019) yapmış 
oldukları çalışmalarda rekreasyon kaynaklarının alt- üst yapı ve hizmet kalitesi alanların tercih edilmesinde önemli etkenler arasında olduğu vurgulanmışlar ve bu unsurların alanlarda kısmen mevcut olmasının yeterli olmayacağı hem sayı hem de nitelik olarak önemli iyileştirilmelerin yapılması ile ancak istenilen hizmet kalitesinin elde edilebileceği vurgulanmıştır. Z6 (Toplam 2650 ha. alan göl aynası altnnda kalacak, 14'i endemik 2'si endemik olmayan nadir olmak üzere toplam 16 adet bitki türünün Deriner Barajı su aynası altında kalması) faktörü ise $0,136^{\prime} l ı k$ öncelik değeri ile zayıf yönler grubunda son sırada yer almıştır (Tablo 5).

Sahanın 9 firsatından birisi olan F1 (Kent merkezi dışında rekreasyon faaliyetlerini gerçekleştirmek için potansiyeli yüksek alternatif bir kırsal rekreasyon alanı niteliğini taşıması) 0.346 yerel öncelik değeri ile ilk sıraya yerleşmiştir. Son sırada ise 0.061 öncelik değeri ile F6 (Yöre halkının rekreatif faaliyetlere katılım göstermeye istekli olması) faktörü yer almıştır (Tablo 6).

Tablo 5. SWOT faktörlerinden "Zayıf Yönlerin" öncelik değerleri

\begin{tabular}{|c|c|c|c|c|}
\hline SWOT faktörleri & $\begin{array}{l}\text { Grubun } \\
\text { öncelik } \\
\text { değerleri }\end{array}$ & SWOT alt faktörler & $\begin{array}{c}\text { Alt faktörlerin } \\
\text { öncelik } \\
\text { değerleri }\end{array}$ & $\begin{array}{c}\text { Genel } \\
\text { öncelik } \\
\text { değerleri }\end{array}$ \\
\hline \multirow[t]{11}{*}{ Güçlü yönler } & 0,390 & G1: Zengin flora, fauna varlığı & 0,405 & 0,158 \\
\hline & & G2: Alan ve yakın çevresinde zengin manzara seyir noktalarının & 0,387 & 0,151 \\
\hline & & bulunması, foto safari olanağına sahip alanların varlığı & & \\
\hline & & G3: Suya dayalı ve çeşitli rekreasyonel faaliyetlere potansiyel oluşturması & 0,362 & 0,141 \\
\hline & & $\begin{array}{l}\text { G4: Alanın konumunun Artvin karayolu koridoru üzerinde ulusal ana } \\
\text { ulaşım ağı üzerinde yer alması }\end{array}$ & 0,346 & 0,135 \\
\hline & & G5: Değişik rekreasyonel faaliyetlere olanak sağlayan topografik yapı & 0,294 & 0,115 \\
\hline & & G6: Dünyanın önemli vadilerinden ve nehirlerinden biri olan & 0,292 & 0,114 \\
\hline & & Çoruh vadisi ve Çoruh nehrinin varlığı, & & \\
\hline & & G7: Macera ve keşif duygusu uyandıran alanların varlığı & 0,290 & 0,113 \\
\hline & & $\begin{array}{l}\text { G8: Barajın inşa edilmesi ile nehir habitatı göl habitatına } \\
\text { dönüşerek yeni bir göl ekosisteminin oluşması }\end{array}$ & 0,286 & 0,112 \\
\hline & & $\begin{array}{l}\text { G9: Başta su kuşları olmak üzere alana dinlenme, beslenme, } \\
\text { barınma hatta kuluçka dönemleri için kuş türlerinin gelmesi }\end{array}$ & 0,285 & 0,111 \\
\hline
\end{tabular}

Tablo 6. SWOT faktörlerinden "Fırsatların" öncelik değerleri

\begin{tabular}{|c|c|c|c|c|}
\hline SWOT faktörleri & $\begin{array}{l}\text { Grubun } \\
\text { öncelik } \\
\text { değerleri }\end{array}$ & SWOT alt faktörler & $\begin{array}{l}\text { Alt faktörlerin } \\
\text { öncelik } \\
\text { değerleri }\end{array}$ & $\begin{array}{l}\text { Genel } \\
\text { öncelik } \\
\text { değerleri }\end{array}$ \\
\hline \multirow[t]{9}{*}{ Firsatlar } & 0,266 & $\begin{array}{l}\text { F1:Kent merkezi dışında rekreasyon faaliyetlerini gerçekleştirmek için } \\
\text { potansiyeli yüksek alternatif bir kırsal rekreasyon alanı niteliğini taşıması }\end{array}$ & 0,346 & 0,092 \\
\hline & & $\begin{array}{l}\text { F2: 1960'lı yıllara kadar Çoruh nehri üzerinde taşımacılık faaliyetinin } \\
\text { yapılmış olması }\end{array}$ & 0,194 & 0,052 \\
\hline & & F3: Yönlendirilebilecek işgücünün varlığı & 0,130 & 0,035 \\
\hline & & $\begin{array}{l}\text { F4: Yerel yönetimlerin rekreasyon çalışmalarına yönelik ilgisi ve yatıım } \\
\text { yapmaya istekli olması }\end{array}$ & 0,249 & 0,066 \\
\hline & & $\begin{array}{l}\text { F5: Baraj gölü ve çevresinde rekreasyonel etkinlikleri yapmaya } \\
\text { yönelik artan ilgi çekicilik }\end{array}$ & 0,315 & 0,084 \\
\hline & & F6: Yöre halkının rekreatif faaliyetlere katılım göstermeye istekli olması & 0,061 & 0,016 \\
\hline & & $\begin{array}{l}\text { F7: Macera ve keşif duygusu uyandıran, görülmeye değer manzaraya } \\
\text { sahip alanların varlığı }\end{array}$ & 0,316 & 0,084 \\
\hline & & F8: Baraj ve çevresinde yeni mesire ve dinlenme alanlarının oluşması & 0,253 & 0,067 \\
\hline & & $\begin{array}{l}\text { F9: Göl kıyısında kurulacak olan yeni Zeytinlik köyünün manzara } \\
\text { avantajından yararlanılarak, kırsal turizme ev sahipliği yapabilecek } \\
\text { bir yapıya dönüştürülmesi }\end{array}$ & 0,263 & 0,070 \\
\hline
\end{tabular}


Tablo 7. SWOT faktörlerinden "Tehditlerin" öncelik değerleri

\begin{tabular}{|c|c|c|c|c|}
\hline SWOT faktörleri & $\begin{array}{l}\text { Grubun } \\
\text { öncelik } \\
\text { değerleri }\end{array}$ & SWOT alt faktörler & $\begin{array}{l}\text { Alt faktörlerin } \\
\text { öncelik } \\
\text { değerleri }\end{array}$ & $\begin{array}{l}\text { Genel } \\
\text { öncelik } \\
\text { değerleri }\end{array}$ \\
\hline \multirow[t]{7}{*}{ Tehditler } & 0,213 & $\begin{array}{l}\text { T1: Zeytin bahçelerinin sular altında kalması, zeytin tarımı yapılacak } \\
\text { uygun arazinin kısıtlı olması }\end{array}$ & 0,327 & 0,070 \\
\hline & & $\begin{array}{l}\text { T2: Köy yerleşimlerinin yer değiştirmesi ile yapılan meskenlerin } \\
\text { tamamında geleneksel mimariden uzak konutların inşa edilmesi, }\end{array}$ & 0,305 & 0,065 \\
\hline & & $\begin{array}{l}\text { T3: Doğal, kültürel ve tarihi mirasın korunması konusundaki yetersizlikler } \\
\text { ve baraj altında kalan tarihi eserlerin korunmasında yaşanan zorluklar }\end{array}$ & 0,251 & 0,053 \\
\hline & & $\begin{array}{l}\text { T5: Çevreye ilişkin yasal mevzuatın yetersizliği, mevzuata uyulmaması ve } \\
\text { yasal bir yaptırımın olmaması, }\end{array}$ & 0,018 & 0,004 \\
\hline & & $\begin{array}{l}\text { T6: Erozyon alanlarının varlığı rekreasyon alanlarını olumsuz yönde } \\
\text { etkilemesi }\end{array}$ & 0,023 & 0,005 \\
\hline & & $\begin{array}{l}\text { T7: Yapılan rekreasyonel faaliyetler sonucu doğal hayatın zarar } \\
\text { görmesine, bitki örtüsünün bozulmasına ve buna bağlı olarak yörenin } \\
\text { estetik değerlerinin azalması }\end{array}$ & 0,202 & 0,043 \\
\hline & & $\begin{array}{l}\text { T8: Alanda yol yapım çalışmalarından kaynaklı bozulmuş olan alanlarda } \\
\text { onarım çalışmalarının yetersiz olması }\end{array}$ & 0,024 & 0,005 \\
\hline
\end{tabular}

4 tehdit arasında $0.321^{\prime}$ lik bir yerel öncelik değeri alan T2 (Turizmle birlikte çevre kirliliği, trafik ve gürültü gibi sorunların ortaya çıkması) ve T3 (Turizmle birlikte doğal, tarihi ve arkeolojik yapının bozulması) faktörleri önem açısından ilk sırada yer alırken, son sırada 0.122 ile T4 (Ekonomik olarak turizmin pahalılığa neden olması) faktörü yer almıştır. Tehditlerin kendi içerisindeki tutarlıık oranı (TO) 0.09 bulunmuş ve matrisin tutarlı olduğu kabul edilmiştir (Şekil 5). Sonuç olarak, sahanın sözel SWOT analizinin tüm faktörleri, Analitik Hiyerarşi Yönetimi'yle sayısal hale getirilmiş ve öncelik sıralamasına konulmuştur (Tablo 7).

Araştırmanın son aşamasında "Alternatif Stratejilerin" oluşturulmasında görüşlerini bildirecek uzman olarak katılan kathlımcıların yaptıkları değerlendirmelerde; zayıflıklar yada tehditler nasıl etkisiz hale getirilebilir ya da bunlar nası üstünlüğe yada bir firsat haline dönüştürülebilir, sahip olunan firsatlar nasıl bir üstünlük haline getirilebilir, var olan üstünlük pazara uygun hale getirilebilir mi, sahip olunan ürün ve hizmetler değişim talepleri doğrultusunda nasıl değiştirilebilir sorularının cevapları olabileceği düşünülen stratejiler arasından seçim yapılmasına ilişkin karar verilmiştir. SWOT analizi ve AHS tekniğinin bir arada kullanıldığı bu çalışmada Deriner barajı ve çevresinin rekreasyonel potansiyelinin daha iyi bir şekilde değerlendirilebilmesine yönelik olarak 3 ana 7 alt strateji belirlenmiştir. Bu belirlenen stratejiler; S1:Geliştirme Stratejileri, S2: Pazarlama Stratejisi ve S3: Ziyaretçi Yönetim stratejileri olmak üzere 3 ana ve 7 alt strateji belirlenmiştir. 7 alt strateji olarak ise geliştirme stratejilerinden; (S1A) baraj ve çevresinde rekreasyon amaçlı projeler geliştirilerek uygulanmasının desteklenmesi, (S1B) baraj ve çevresindeki mevcut rekreasyon alanlarının alt yapı ve hizmet kalitelerinin iyileştirilmesi, (S1C) baraj ve çevresinde rekreasyonel faaliyetlerin geliştirilmesi için yerel yatırımcıların desteklenmesi, pa-

Tablo 8. Alternatif stratejiler

\begin{tabular}{ll}
\hline Alternatif stratejiler & \\
\hline S1(Geliştirme Stratejileri) & S1A; Baraj ve çevresinde rekreasyon amaçlı projeler geliştirilerek uygulanmasının desteklenmesi \\
& S1B; Baraj ve çevresindeki mevcut rekreasyon alanlarının alt yapı ve hizmet kalitelerinin iyileştirilmesi \\
S1C; Baraj ve çevresinde rekreasyonel faaliyetlerin geliştirilmesi için yerel yatıımcıların desteklenmes
\end{tabular}


Tablo 9. Tüm nitel faktörlere göre stratejilerin değerlendirilmesi

\begin{tabular}{|c|c|c|}
\hline & Öncelik değerleri & \\
\hline Güçlü Yönler & 0,390 & \\
\hline Zayıf Yönler & 0,257 & \\
\hline Firsatlar & 0,266 & \\
\hline Tehditler & 0,213 & \\
\hline Stratejiler & Alt Stratejiler & Öncelik değerleri \\
\hline \multirow[t]{3}{*}{ Geliştirme Stratejileri } & $\begin{array}{l}\text { Baraj ve çevresinde rekreasyon amaçlı projeler geliştirilerek uygulanmasının } \\
\text { desteklenmesi }\end{array}$ & 0,576 \\
\hline & $\begin{array}{l}\text { Baraj ve çevresindeki mevcut rekreasyon alanlarının alt yapı ve hizmet } \\
\text { kalitelerinin iyileştirilmesi }\end{array}$ & 0,486 \\
\hline & $\begin{array}{l}\text { Baraj ve çevresinde rekreasyonel faaliyetlerin geliştirilmesi için yerel } \\
\text { yatırımcıların desteklenmesi }\end{array}$ & 0,238 \\
\hline Pazarlama Stratejisi & $\begin{array}{l}\text { Baraj ve yakın çevresinde bulunan yerleşim yerlerine ait yöresel ürünleri, } \\
\text { yerel mimarinin, tarihi ve kültürel kaynak değerlerinin ön plana çıkarılması }\end{array}$ & 0,215 \\
\hline \multirow[t]{3}{*}{ Ziyaretçi Yönetim Stratejileri } & Gelen ziyaretçilerin yeme içme imkanlarının genişletilmesi & 0,247 \\
\hline & $\begin{array}{l}\text { Gelen ziyaretçiler için hem su yüzeyinde hem de su kıyısında farklı rekreasyonel } \\
\text { aktivitelerin ve rotaların geliştirilmesi }\end{array}$ & 0,330 \\
\hline & Belirli periyotlar halinde denetleme ve kontrollerin yapılması & 0,170 \\
\hline
\end{tabular}

zarlama stratejisi; (S2A) baraj ve yakın çevresinde bulunan yerleşim yerlerine ait yöresel ürünleri, yerel mimarinin, tarihi ve kültürel kaynak değerlerinin ön plana çıkarılması ve ziyaretçi yönetim stratejilerinden; (S3A) gelen ziyaretçiler için hem su yüzeyinde hem de su kıyısında farklı rekreasyonel aktivitelerin ve rotaların geliştirilmesi, (S3B) gelen ziyaretçilerin yeme içme imkanlarının genişletilmesi ve (S3C) belirli periyotlar halinde denetleme ve kontrollerin yapılması olarak belirlenmiştir (Tablo 8).

Yapılan öncelik değerleri hesaplaması sonucu Deriner Barajı ve çevresinde turizm ve rekreasyonel potansiyelinin değerlendirilmesinde ve seçiminde en uygun izlenecek stratejinin baraj ve çevresinde rekreasyon amaçlı projeler geliştirilerek uygulanmasının desteklenmesi stratejisi olduğu tespit edilmiştir (Tablo 9).

\section{Sonuç ve Öneriler}

Gerçekten de bir yörede turistik ve rekreasyonel faaliyetlerin geliştirilebilmesi için öncelikle potansiyel doğal ve kültürel turistik kaynak değerlerinin saptanması daha sonra da bu kaynakların rekreasyonel ve turistik amaçı ıasıl değerlendirilebileceğinin ortaya konulması gereklidir (Akova, 2000; Akbulak 2016). Günümüzde yoğun ve hızlı geçen kent yaşamı, hızla artmakta olan yapılaşma sonucu yeşil alanların azalması ve ağırlaşan yaşam koşulları sonucu ortaya çıkan rekreasyon ihtiyaçlarını kentlerin yakın çevrelerinde bulunan doğal alanlar, su kaynakları, korunan alanlar vb. alanları tercih etmektedirler.

Son yıllarda yapılan araştırmalarda rekreatif faaliyetler için su kaynakları ve yakın çevrelerinin tercih edilme oranlarının oldukça yüksek olduğu görülmektedir. Fakat su kıyılarına olan talebin giderek artması ile birlikte bu kaynakların daha sağlıklı ve doğru kullanılabilmeleri amacıyla planlamaların yapılması gerekliliği ortaya çıkmıştır. Özellikle Avrupada ekonomik ömrünü doldurmuş olan birçok baraj gölünün kullanımlarına yönelik planlamalar uzun yıllardır yapılmaktadır.

Araştırma alanı ziyaretçilerin doğa sporlarına yönelik aktif ve pasif çeşitli faaliyetlerde bulunmaları ve yöreye özgü kültürü tanımaları için firsatlar yaratabilecek konumdadır. Deriner Baraj Gölü ve yakın çevresinde piknik, manzara seyri gibi rekreasyonel aktiviteler zaten yapılmaktadır. Bu yapılan aktiviteler kıyı bölgesine yakın, arazi yapısı az eğimli alanları kapsayan, ulaşım ve erişim kolaylığı olan, mevcut rekreasyon alanları ile ilişki kurabilecek özellikteki alanlar çevresinde yoğunlaştı̆̆ı görülmektedir.

Karaşah (2016) tarafindan yapılan ve Artvin kentinde kentsel ve kırsal rekreasyon alanlarına yönelik kullanıcı tercihlerinin belirlenmesini konu alan çalışmada ilin rekreasyonel potansiyelinin daha etkin değerlendirilmesi ve gelir yaratacak bir yapıya kavuşturulması için kent yakın çevresinde bireylerin daha kısa zamanda ulaşabilecekleri ve daha fazla etkinlik gerçekleştirebilecekleri rekreasyon alanları planlanmasının ve tasarlanmasının gerektiği önerilmiştir.

Surat (2017) tarafindan yapılan çalışmada da Deriner baraj gölü ve çevresinde suya dayalı birçok rekreasyonel aktiviteye önemli potansiyel oluşturan alanların mevcut olduğunu belirtmiş, bu alanda rekreasyonel faaliyetlerin geliştirilmesine yönelik öneriler getirmiştir. Aynı zamanda 
Deriner barajı ve çevresinde yapılacak rekreasyonel faaliyetlerin sürdürülebilirliği için doğru planlama stratejilerinin uygulanması gerektiği belirtilmiştir.

Yapılan değerlendirmeler sonucu çalışma alanının sahip olduğu zengin flora, fauna varlığı, baraj alanı ve yakın çevresinde zengin manzara seyir noktalarının bulunması, foto safari olanağına sahip alanların varlığı ve kent merkezi dışında rekreasyon faaliyetlerini gerçekleştirmek için potansiyeli yüksek alternatif bir kırsal rekreasyon alanı niteliğini göstermesi firsat niteliği taşıyan güçlü yönler olarak karşımıza çıkarken, rekreasyona yönelik hizmet sektörünün gelişmemiş olması ve altyapı ve hizmet kalitesinin ihtiyacı karşılayamaması ve 2 köy yerleşiminin (Zeytinlik ve Oruçlu) ve yerleşimlerde bulunan kültürel miras unsurlarının baraj suları altında kalması çevre kirliliği, trafik ve gürültü gibi sorunların ortaya çıkması ve mevcut doğal, tarihi ve arkeolojik yapının bozulması gibi unsurlarda alanı tehdit eden zayıf yönler olarak karşımıza çıkmaktadır.

Yine yapılan değerlendirmeler sonucu, bu güçlü yönler ve firsatlar kullanarak zayıflıklar yada tehditler nasıl etkisiz hale getirilebilir ya da bunlar nasıl üstünlüğe yada bir firsat haline dönüştürülebilir hususunda baraj ve çevresinde rekreasyon amaçlı projeler geliştirilerek uygulanmasının desteklenmesi, gelen ziyaretçiler için hem su yüzeyinde hem de su kıyısında farklı rekreasyonel aktivitelerin ve rotaların geliştirilmesi ve baraj ve çevresindeki mevcut rekreasyon alanlarının alt yapı ve hizmet kalitelerinin iyileştirilmesi yönünde alt stratejiler ön plana çıkmıştır. Bu stratejiler dışında da ek önerilerde aşağıda sunulmuştur.

- Yapılan planlama çalışmaları ile rekreasyonel faaliyetlerin yılın tamamına yayılmasına ve bu çerçevede ildeki potansiyel rekreasyon alanların yılın hangi döneminde hizmet verebileceği belirlenerek, entegre rekreasyonel aktivite rotaları oluşturulmalıdır. Özellikle rekreasyonel potansiyelinin yüksek olduğu korunan alanlar, su kıyıları ve çevreleri gibi alanlarda altyapı hizmetlerinin iyileştirilmesine öncelik verilmelidir.

- Ildeki rekreasyonel faaliyetler ile ilgili en önemli sorunlardan biri bu alanda hizmet veren yerel yatrımcılar ve bu alanda görev yapan paydaşlar arasındaki eşgüdüm eksikliği ve işbirliği yetersizliğidir. Rekreasyonel faaliyetlerin ve alanlarının geliştirilebilmesi için yapılan tüm plan, tasarım, alt yapı, tanıtım gibi çalışmalar birbirine bağı̆ıdır. Bu nedenle rekreasyon hizmeti veren tüm yatırımcıların ve kamu yetkililerin işbirliği içinde çalışarak kaliteli hizmet verebilecek alt ve üst yapı projelerin geliştirilebilmesi yönünde yatırımcıların desteklenmesi önemli bir husustur. Bu çerçevede yöredeki yerel halkında beklentileri de mutlaka göz önünde bulundurulmalıdır.

- Artvin ilindeki doğal, tarihi ve kültürel kaynakların rekreasyon kullanım amaçlı değerlendirilebilmesinde tanıtım ve pazarlama faaliyetleri büyük önem taşımaktadır. Bu faa- liyetlerde kamu ve özel sektör temsilcilerinin işbirliği içinde olması ve özellikle seyahat acentelerinin etkin bir rol üstlenmesi gereklidir. Özellikle rekreasyonel potansiyeli yüksek olan baraj alanları ve çevrelerinde bulunan kırsal yerleşimlerdeki önemli doğal, tarihi ve kültürel değerlerin tanıtımının yapıldığı broşür ve kitapçıkların basılması bu alanların daha fazla kitle tarafindan bilinirliklerinin artmasına ve alternatif olmasına katkı sağlayabilir. Ayrıca yerel ürünleri tanıtıcı sergilerin düzenlenmesi ve yöredeki festivallerin zenginleştirilerek devam ettirilmesi rekreasyonel faaliyetlerin gelişmesi ve katılım sağlanabilmesi açısından önemlidir.

- Deriner baraj ve çevresi doğal, tarihi ve kültürel değerleri itibariyle rekreasyonel kullanıma yönelik açısından çok zengin bir potansiyel taşımaktadır. Ancak su kıyıları ve yakın çevrelerinde rekreasyonel kullanımlarına yönelik çaıışmalarının sağııkı bir şekilde planlanması için ayrıntılı bir envanter ve haritalama çalışmasına intiyaç duyulmaktadır. Bu çerçevede geniş çaplı bir envanter çalışması yapılmalı ve Coğrafi Bilgi Sistemleri ortamında ayrıntılı veri tabanı oluşturulmalıdır. Bu veri tabanı yöredeki rekreasyonel faaliyetlerinin planlanmasında kullanılabileceği gibi interaktif haritalar yardımıyla kullanıcıların erişimine de açılabilir.

Sonuç itibariyle Artvin Deriner barajı ve yakın çevresi doğal ve kültürel özellikleriyle rekreasyonel açıdan önemli bir potansiyel barındırdığı tespit edilmiştir. Bu potansiyelin uygun bir şekilde değerlendirilmesine yönelik olarak Deriner barajı ve çevresinde yapılacak rekreasyonel faaliyetlerin gerçekleştirilmesiyle ilin kalkınmasına önemli katkılar sağlanabilir. Aynı zamanda su ile ilişkili olan alanlardaki doğal, kültürel ve tarihi kaynakların sürdürülebilir bir şekilde kullanılmasını mümkün kılmaktadır.

Bu çalışmada, SWOT analizi ve AHS tekniğinin birlikte kullanılması ile alanların rekreasyonel kullanımına yönelik stratejilerinin belirlenmesinde faydalı ve etkin yöntem olduğunu göstermiştir. SWOT analizi ile Deriner barajı ve çevresinin rekreasyonel kullanımı açısından güçlü ve zayıf yönleri ile karşılaşabileceği firsat ve tehditler ortaya konmuş, AHS tekniği ise SWOT faktörlerinin stratejilerin geliştirilmesindeki önceliklerinin belirlenmesinde kullanılmıştır. Böylece nitel bir özellik gösteren SWOT analizi, AHS tekniği yardımıyla nicel bir özellik kazanmış ve stratejilerin geliştirilmesinde ağırlık puanları yüksek olan faktörler ön plana çıkarılabilmiştir. Çalışmanın bu yönüyle benzer araştırmalar için model olabileceği düşünülmektedir. Diğer taraftan bu çalışmada ortaya konulan stratejilerin yerel yöneticiler ve karar vericiler tarafindan dikkate alınmasının, Artvin kentinin yakınında bulunan su kaynaklarının rekreasyonel potansiyelinin doğru bir şekilde değerlendirilmesine önemli katkılar sağlayacağı düşünülmektedir.

Teşekkür

*Bu araştırma, Artvin Çoruh Üniversitesi Bilimsel Araştorma Projeleri (BAP) Koordinasyon Birimi tarafindan des- 
teklenen "Deriner Baraj Gölü ve Yakın Çevresinde Suya Dayanıklı Rekreasyonel Faaliyetlerin Planlanması Üzerine Bir Araştırma" başlıklı 2013.F12.02.05 nolu projeden üretilmiştir.

\section{Kaynaklar}

Albay, N. (2006). Üsküdar-Haydarpaşa Arası Kıyı Düzenlemesinin Rekreasyonel Açıdan Değerlendirilmesi, Bahçeşehir Üniversitesi Fen Bilimleri Enstitüsü Çevre Tasarımı Yüksek Lisans Programı, Yüksek Lisans Tezi, İstanbul.

Akbulak, C. (2016). Ardahan İlinde Kırsal Turizm Potansiyelinin Sayısallaştıılmış Swot Analizi Ile Değerlendirilmesi. Humanitas: International Journal Of Social Sciences, 4(7).

Akten M. (2003). Isparta Illindeki Bazı Rekreasyon Alanlarının Mevcut Potansiyellerinin Belirlenmesi. Süleyman Demirel Üniversitesi Orman Fakültesi Dergisi, Seri: A, Sayı: 2, ISSN: 1302-7085, s. 115-132. Isparta.

Akova, i. (2000). Alternatif Turizm Olanaklarımız. Coğrafya Dergisi, 8, 71-84.

Altunöz, Özlem; Tırıl, Alpay; ve Arslan, Ömer Emre, (2014), “Hamsilos Tabiat Parkı'nın Rekreasyon Potansiyelini Belirlemeye Yönelik Bir Araştrrma" Journal of Recreation And Tourism Research (JRTR), Y.1, S.1, s. 20-38.

Anonim, (2011). Çoruh Vadisi (Artvin) - Deriner Barajı Su Aynası Altnnda Kalacak Alanda Bulunan Risk Altnndaki (Endemik Ve Endemik Olmayan Nadir) Bitkilerin Tespiti, Nakledilmesi Ve Yetiştirilmesi Projesi“ Orman Ve Su İ̧̧leri Bakanlığı, Çölleşme Ve Erozyonla Mücadele Genel Müdürlüğü; s. 20.

Anonim, (2014). Ekonomıde Dönüsüm Saglayan Projeler. İnsan Dergisi, Türkıye Insaat Sanayıcılerı Isveren Sendıkası Yayınları. Mart - Nisan 2014; s. 108.

Balcı, A. (2005). Sosyal Bilimlerde Araştırma. Ankara: Pegem A Yayıncilık.

Bayraktar, A. (1972). Rekreasyon Turizm İlişkileri Ve Bu Konular ile Illgili Tesislerde Peyzaj Planlamanın Önemi, Peyzaj Mimarlığı, 3.

Bekar, M., Sekban, D., Ve Cengiz, A. (2018). Trabzon Sera Gölü'nün Rekreasyon Potansiyelinin Kullanıcı İstekleri Doğrultusunda Belirlenmesi. Akademik Sosyal Araştrmalar Dergisi, Yıl: 6, Sayı: 72, Haziran 2018, s. 349-359.

Birdir, K., Karakan, H. İ. ve Çolak, O. (2016). “Gaziantep ilinin Turizm Açısından Swot Analizi Ve Turizmin Geliştirmesine Yönelik Öneriler." Seyahat Ve Otel İşletmeciliği Dergisi 13.1.

Boud-Bovy, M., Lawsom, F. (1998). Tourism-Recreation Handbook Of Planning And Design, Architectural Pres, Isbn: 07506 30868.

Bozkurt, S. G., (2016), "Gürün (Sivas) illçesinin Rekreasyon Kaynaklarının Belirlenmesi ve Değerlendirilmesi", Journal of the Faculty of Forestry Istanbul University, Y. 66, S.1, s. 318-328.

Cendere, A. (1998). Su Elemanlarının Kentsel Mekanlarda Ve Yeşil Alanlarda Kullanımı, Yüksek Lisans Tezi, İstanbul Teknik Üniversitesi Fen Bilimleri Enstitüsü, İstanbul.

Cetin, M. (2015). Evaluation of the sustainable tourism potential of a protected area for landscape planning: a case study of the ancient city of Pompeipolis in Kastamonu. International Journal of Sustainable Development \& World Ecology, 22(6), 490-495.

Doğanay, H., ve Zaman, S. (2013). Türkiye Turizm Coğrafyası. (Güncellenmiş 4. Baskı), Pegem Akademi Yayınevi, Ankara.
Doğaner, S. (2001). Türkiye Turizm Coğrafyası, Çantay Kitabevi, İstanbul.

Fairbrother, N. (1976). The Natural Of Landscape Design. The Architectural Press, s. 79. London.

Güngör, S., ve Arslan, M. (2004). Turizm ve Rekreasyon Stratejileri Için SWOT Analizi, Görsel Kalite Değerlendirmesi, Turizm Tesislerinin Beğenilirliği ve Turizm Tesisleri Durum Analizi Uygulamasi: Beyşehir İlçesi Örneği. Selçuk Tarım ve Gıda Bilimleri Dergisi, 18(33), 68-72.

Hamamcıoğlu C. (2005). Kentlerin Suyolu Girişlerinde Geçmişten Günümüze Yaşanan Aşamalar Ve Kentsel Tasarım TMMOB Şehir Plancıları Odası Süreli Yayınlar Planlama Dergisi Yıl: 2005 Sayı: 3 Ankara.

Hattapoğlu, Z. (2004). Su Olgusunun Yerleşmeler Evrimindeki Yeri Ve Günümüzde Bir Kentsel Tasarım Elemanı Olarak Yeniden Yorumlanması. Yüksek Lisans Tezi, Mimar Sinan Üniversitesi, Fen Bilimleri Enstitüsü, s. 176.

Heydarzadegan, P. (2013). İran-Merağa İli Peyzaj Özelliklerinin Turizm Potansiyeli ve Hareketliliği Açısından Değerlendirilmesi. Doktora Tezi. Ankara Üniversitesi, Fen Bilimleri Enstitüsü, Peyzaj Mimarlığı Anabilim Dalı, Ankara.

Kajanus M., Kangas J., and Kurtilla M. (2004). 'The use of value focused thinking and the A'WOT hybrid method in tourism management', Tourism Management, S. 25, s. 499-506.

Kangas, J., Pesonen, M., Kurtilla, M., and Kajanus, M. (2001). 'A'WOT: Integration the AHP with Swot analysIs', 6th ISAHP 2001 Berne, Switzerland, August 2-4.

Karahan, F., ve Orhan, T. (2009). “Çoruh Havzası Uzundere Vadisi'nin Kırsal Rekreasyon Planlaması Yönünden Suya DayaIı Olanakları." Kırsal Çevre Ve Ormancılık Sorunlarını Araştırma Derneği, Kırsal Çevre Yıllığı, 54-81.

Khazim, A. (1990). Metropoliten Alanlar İçinde Kalan Su Kıyılarının Rekreasyonel Kullanımı "Ankara Mogan Gölü" Örneği, Gazi Üniversitesi Fen Bilimleri Enstitüsü Şehir Ve Bölge Planlama Anabilim Dalı, Ankara.

Kılıç, A. (2001). Kent Kıyılarının Dönüşümünde Endüstriyel Miras Kavramı: İstanbul İstinye Tersanesi, Türkiye'nin Kıyı Ve Deniz Alanları 3. Ulusal Konferansı 2001, Kıyı Alanları Yönetimi Türkiye Milli Komitesi, Orta Doğu Teknik Üniversitesi, Ankara, s. 127-134.

Koçan, N. (2012). Kızılcahamam-Çamlıdere jeoparkında kırsal peyzaj ve rekreasyon planlama. Erciyes Üniversitesi Fen Bilimleri Enstitüsü Dergisi, 28(1), 38-46.

Memlük, Y. (1977). Bursa Şehri Ve Çevresi İçin Rekreasyon Sisteminin Saptanması Üzerinde Bir Araşttrma, Doktora Tezi (Yayımlanmamış), AÜ Fen Bilimleri Enstitüsü.

Okuyucu, Ö., ve Menteşe, Ö. (2019). Pelitözü Göleti Ve Çevresinin Rekreasyonel Kullanımı Ve Doğal Çevre Üzerine Etkileri. Akademik Sosyal Araştırmalar Dergisi, Yıl: 7, Sayı: 87, Ocak 2019, s. 399-409

Önen, M. (2007). Kentsel Kıyı Mekanı Olarak Akarsuların Rekreasyonel Kullanım Potansiyelinin İrdelenmesi: Eskişehir Porsuk Çayı Ve İstanbul Kurbağalı Dere Örneği, İstanbul Üniversitesi Fen Bilimleri Enstitüsü Peyzaj Mimarlığı Anabilim Dalı, Yüksek Lisans Tezi, İstanbul.

Özan, M. B., Polat, H., Gündüzalp, S., ve Yaraş, Z. (2015). Eğitim Kurumlarında Swot Analizi. Turkish Journal Of Educational Studies, 2(1), 1-28.

Özkan, B., ve Kaplan, A. (1992). İzmir Kuş Cennetinin Rekreasyo- 
nel Turizm Yönünden Önemi. Turizm Yıllığı.

Saaty, T. L. (1980). The Analytic Hierarchy Process. McGraw-Hill, New York.

Taşcıoğlu, S., ve Akpınar, N. (2016). A'WOT Analizi Tekniği İle Turizm Alanlarının Değerlendirilmesi: Kuzey Antalya Kültür Ve Turizm Koruma Ve Gelişim Bölgesi Örneği. Journal Of International Social Research, 9(42).

Tanrıvermis, E. 2000. Ankara Koşullarında Suya Dayalı Rekreasyon-Spor Faaliyetlerinin Planlanması Üzerine Bir Araştirma, Doktora Tezi.

Tocher, S., Driver, B. (1970). Towards A Behavioral Esthetics: The On Of Recreational Engegament, With Implications For Planning, Element Of Outdoor Recreation Planning. An Arbor: Michigan University Press.

Topay, M., \& Memlük, Y. (2011). Rekreasyonel etkinlikler için uygun alan seçimine yönelik yeni bir yöntem yaklaşımı: BartınUluyayla örneği. Turkish Journal of Forestry, 12(2), 141-147.

Uğurlu, A. (2005). Rekreasyonel Amaçlı Doğa Sporlarının Turizmde Kullanılması Antalya Köprülü Kanyon Rafting Uygulaması. Yüksek Lisans Tezi, Akdeniz Üniversitesi Sosyal Bilimler Ensti- tüsü, s. 120.

Uslu Ş., Ayaşlıgil T. (2007). Kent Ormanlarının Rekreasyonel Amaçlı Kullanımı Ve İstanbul i̇li Örneğinde İrdelenmesi. YTÜ Mim. Fak. E-Dergisi, Cilt 2, Sayı 4.

Uzun, G., Altunkasa F. M. (1991). Rekreasyonel Planlamada Arz Ve Talep, Ç.Ü. Ziraat Fak. Genel Yayın No:6, Yardımcı Ders Kitapları Yayın No:1, Adana.

William, H. (1973). Environmental And Cognition, Conitive Appreciation Analysis Of Human Special Behavior, Sewner Pres, New York.Wylson, A., 1986. Aquatecture: Architecture And Water. The Architectural Press, s. 151. London.

Yıldırım, A. ve Şimşek, H. (2013). Sosyal Bilimlerde Nitel Araştırma Yöntemleri. 9. Baskı, Ankara: Seçkin Yayıncılık.

Yılmaz, T., ve Özel, E.A. (1999). Islak Alanlarda Rekreatif Olanaklar. A.Ü. Ziraat Fakültesi. Peyzaj Mimarlığı Bölümü. Lisans Tezi. Ankara.

Yılmaz, R. (2006). Saroz Körfezinin Turizm Ve Rekreasyonel Kullanım Potansiyeli Üzerine Bir Araştırma, Süleyman Demirel Üniversitesi Orman Fakültesi Dergisi, Tekirdağ. Seri: A, Sayı: 1, Yıl: 2006, Issn: 1302-7085, s. 124-135. 